\title{
Winners and losers in the Arab Uprisings: A Mediterranean Tourism Perspective.
}

Abstract:

This paper analyses the effects of the recent Arab uprisings on tourism destinations located along the Mediterranean coastline. It uses time-series analysis to model international tourist arrivals. First, autoregressive integrated moving average (ARIMA) models are estimated for the period 1980-2009 and predicted for 2010-2014 to establish suitable country controls. Second, Bayesian Structural Time-Series models - designed primarily to determine causal impacts in on-line marketing campaigns - are used to establish the effects of the events in Tunisia, Egypt, Morocco, Turkey, Spain and Greece. The main conclusion is that the models clearly capture the negative impact of the uprisings in Tunisia and Egypt and their positive impacts on Morocco and Turkey. However, the effects on Spain and Greece are less clear and depend crucially on the set of controls used in the analysis. 


\section{1.-Introduction.}

Inspired by the self-immolation of Mohammed Bouazizi, a frustrated, impoverished fruit vendor whose merchandise was confiscated by authorities, Tunisians took to the streets in December 2010 in a campaign of civil resistance dubbed 'Jasmine Revolution' to protest against the autocracy, corruption, and inequality of the Ben Ali regime. The success of protests in Tunisia inspired people in other Arab countries to rise up against their autocratic rulers in what became known as the Arab Spring (Alexander, 2012).

Undoubtedly, the uprisings of the 'Arab Spring' fostered important political changes in the region, including the overthrow of well-established leaderships and autocrats in Tunisia, Egypt, Libya, and Yemen, or the response to some social pressure of Governments of Morocco, Algeria and Jordan. Pero este proceso también se ha acompañado de inestabilidad y duros enfrentamientos entre gobierno y ciudadanos. La Guerra civil de Siria es el episodio más dramatico desde el punto de vista humanitario, aunque en este caso la Primavera Árabe es solo un episodio más de un conflicto con tintes geopolíticos, y que sirve como caldo de cultivo del terrorismo islámico. Por este motivo, en lo sucesivo utilizaremos el término Arab uprisings o simplemente uprisings para referirnos a estos eventos.

From an economic viewpoint, la inestabilidad que siguió a the Arab Spring uprising had a significant impact on economic activity in North Africa. According to Deutsche Bank Research (2013) in the short-run, average real GDP growth in the region fell from $4.2 \%$ in 2010 to $2.2 \%$ in 2011, its lowest level in a decade. The slowdown affected hardest in countries that were at the center of the uprisings, such as Libya, Tunisia, Egypt, Syria and Yemen. Only Morocco maintained a low growth in its GDP during 2011. In 2013 the GDP growth rates remained below the pre-revolutionary levels. 
Obviously, esta etapa de inestabilidad también ha tenido su reflejo en el turismo, una industria en la que safety and security are main determinants of competitiveness (Dwyer \& Kim, 2003). In fact, wars, terrorism and economic crisis, instead of natural disasters are key factors in so-called "tourism crisis", defined by the Pacific Asia Travel Association as "a disaster, whether natural or man-made, that has the potential to totally disrupt the tourism industry" (Perles et. al, 2013).

As a result, the number of tourist arrivals in the five main destinations in the region Egypt, Tunisia, Morocco, Jordan and Lebanon - fell considerably - the decline was most severe in Egypt and Tunisia, by about $40 \%$ each -, y al mismo tiempo se ha reducido la inversion extranjera internacional en el sector.

According to Mansfeld and Winckler (2015), terrorism and other causes (like the absence of empathy with the current political regimes, or the lack of available foreign aid to re-activate tourism flows) have alarmed European tourists, many of whom have retreated to the north shore of the Mediterranean and Dubai for their holidays.

Ante estos hechos, en this paper se pretende to study the impact of the uprisings and la posterior inestabilidad política on the tourism flows, determining if there are winners and losers in Mediterranean touristic countries. To do that, we will take Egypt, Greece, Morocco, Spain, Tunisia and Turkey and will use Bayesian Structural Time-Series models proposed by Brodersen et al. (2015). This methodology allows us to infer the causal impact based on a diffusion-regression state-space model that predicts the counterfactual market response in a synthetic control that would have occurred had no intervention taken place.

Instead of crises in tourism have been deeply studied, to our knowledge, this is the first attempt to determine the impact of the Arab uprisings on tourism using econometric 
methods that go beyond descriptive time series analysis. Apart of that, this research is innovative in three ways: (1) considers a broader period of analysis, (from 2010 to 2014), than previous studies (see for example Beck, 2014) estimating the immediate effects of the Arab Spring, (2) it seeks to estimate the impact of these events on tourist arrivals by adapting a methodology designed to capture causality using observational data, and (3) finally, it introduces a discussion about the most suitable set of country controls needed to estimate causal impacts on tourism.

The paper proceeds as follows. Sections two and three review the existing literature on tourism crisis and terrorism, and study the evolution of tourism in the Mediterranean Arabian countries during the last decades. Section four describes the methodology and data. Section five deals with the econometric analysis. Section six presents the conclusions as well as the limitations of the analysis performed.

\section{2.-Literature review.}

Crises and their management constitute a popular topic for tourism researchers, and many studies on the characteristics of crises and the action taken to overcome them have been carried out (Henderson, 1999). Hall (2010) summarizes various types of tourism crises and explores their treatment by tourism researchers pointing out that crises with respect to international tourism are usually interrelated with other crisis events in economics and finance, politics and energy. Thus, research on economic crisis has tended to go hand-in-hand with major regional and global periods of recession and downturn in international tourism.

A successful tourism industry needs political stability, peace, security, and the potential for intercultural dialogue between groups of people without mental or physical restrictions (Al-Hamarneh \& Steiner, 2004). Poor personal security arising from violent 
protests, social unrest, civil war, terrorist actions, and violation of human rights or only a threat of these actions may have negative effects on the tourist industry (Hall \& O'Sullivan, 1996). The large amount of existing literature is logical due to the relevance of the topic (Ritcher \& Waugh, 1986).

Singh (2013) surveys the existing literature distinguishing between authors analyzing the economic impact of terrorism (Enders \& Sandler, 1991; Enders, Sandler \& Parise, 1992), authors studying the impact of political instability or war on tourism (e.g. Gartner \& Shen, 1992; Mansfeld and Kliot, 1996; Mihalic, 1996; Ritcher, 1980; 1989; Schwartz, 1991; Scott, 1988; Smith, 1996; Teye, 1986) and authors focusing on the implications for tourism marketing and crisis management (e.g. Buckley and Klemm, 1993; Conant, Clarck, Burnett \& Zank, 1988; D’Amore and Anuza, 1986; Hollier, 1991; Hurley, 1988; Sönmez, Backman \& Allen, 1994). An analysis of the above studies reveals that terrorists target tourists in order to destabilize the economic health of a destination and to grab media attention. Gaining a political advantage over the government by reducing their earnings of foreign exchange constitutes a further reason behind targeting tourist destinations (Hall \& O’Sullivan, 1996; Richer \& Waugh, 1986). War and political instability are not deliberate actions directed at harming the tourism industry, but regrettably the effects are the same.

Apart from these theoretical and empirical works, there are a large number of specific case studies showing the negative impacts of terrorist activities (e.g. Neumayer, 2004; and Yang \& Wong, 2012). Most of them agree that the principal consequences of attacks are a decline in traffic and receipts as has been empirically shown in Spain (Enders \& Sandler, 1991), Norther Ireland (Pizam, 1999), Egypt (Wahab, 1996), China (Gartner \& Shen, 1992), the United States (Lepp \& Gibson, 2003), and of course in the 
Middle East (Avraham, 2015; Mansfeld and Winckler, 2015) where instability and wars have been a constant feature during the last few decades from Libya to Afghanistan.

Moreover, political violence affects a destination not only contemporaneously but also with a lagged effect. Enders \& Sandler (1991) and Enders, Sandler \& Parise (1992) suggest that tourist arrivals can decrease strongly three to nine months after an event, when stability has already been restored. However, the tourism industry can recover rapidly after the end of the conflict (Fisher, 2003).

Likewise, studies highlighting the relevance of crime in tourism destinations (e.g. Brunt \& Hambly, 1999; Korstanje \& Clayton, 2012) show that tourism can provoke an increase in crime and can provide certain conditions for criminals where the gains from crimes against tourists are high and the risks are low. As in the previous cases, adverse publicity from the reporting of crime against tourists is shown to have drastic effects on subsequent tourist numbers (Brunt \& Hambly, 1999). But the impact of instability on destinations depends on the degree of risk aversion for tourists (Lepp \& Gibson, 2003) and the stage of development of destinations (Thompson, 2011).

One of the most studied topics in this context is the effect that instability has on neighboring countries. The literature confirms a substitution effect between destinations when political violence or even terrorism is portrayed (Zheng \& Martin, 1992; Mansfeld \& Kliot, 1996). The final effects of terrorism on tourism flows depend mostly on the intensity and frequency of attacks (Pizam, \& Smith, 2000). So, minor events might result in short-term drops in tourism flows to the particular country while major events can create a spillover effect with adjacent countries also affected through a loss of potential inbound flows (Mansfeld, 1996; Ryan, 1991). 
However, despite these findings, authors disagree in how the political instability of a country affects neighboring countries in the same region. As pointed out by Beck (2014), some authors argue that the detrimental effects on tourism are likely to spill over into other countries (Teye, 1986; Ritcher \& Waugh, 1986). Others suggest that neighboring countries can actually benefit from a substitution effect as long as they are not themselves seen as directly affected by the events of violence (Drakos \& Kutan, 2003; Fielding and Shortland, 2011). Conversely, authors supporting the argument that terrorism or political violence can either have negative spillover effects on neighboring countries in the region or more positive substitution effects are Wall (1996), Lepp \& Gipson (2003), Frey \& Lüchinger (2009) and Enders, Sandler \& Parise (1992). The basis for these effects is the halo effect that can occur with the perception of risk and safety. If a country has a negative image, or is perceived to be unsafe to visit, these problems will be attributed to the whole region (Beck, 2014).

However, based on the Arab countries' experience, Hazbun (2006) concludes that tourism flows are not as vulnerable to political violence as many might assume; and even those areas rocked by violence and war have found alternative market niches (such as journalists, workers, and business travelers seeking post-war reconstruction contracts) to sustain the demand for tourism services.

But in spite of everything, there is a higher level of agreement among authors with respect to the need to manage crises caused by political instability. To avoid the negative effects inherited from these situations, destinations should incorporate crisis management planning into their overall sustainable development and marketing/management strategies to protect and rebuild their image of safety/attractiveness, to reassure potential visitors of the safety of the area, to reestablish the area's functionality/attractiveness, and to aid local travel and tourism industry 
members in their economic recovery (Sönmez, Apostolopoulos \& Tarlow, 1999). Destination Management Organizations and other stakeholders should play an active role in these plans (Paraskevas \& Arendell, 2007).

This paper focuses on the effects of the Arab uprisings on the tourism performance of the affected countries using a time series analysis approach. Studying the effects of terrorism on the tourism industry based on a time-series analysis is not new. Enders \& Sandler (1995) advocates the use of time-series analyses to identify cycles, trends, and irregular components for forecasting purposes and vector-autoregressions (VAR) with respect to the effects of terrorism on tourism. Sloboda (2003) uses an autoregressive moving average with explanatory variables (ARMAX) model to carry out a simple impact analysis. Yaya, (2008) uses a time series method called the 'transfer function' to analyze the effect of terrorism on tourism in Turkey. Raza \& Jawaid (2013) investigate the impact of terrorism activities on tourism in Pakistan by using the annual time series data from the period of 1980 to 2010 and a cointegration analysis (Johansen and Juselius and autoregressive distributed lag models -ARDL- bound testing procedure), confirming a long run relationship between terrorism and tourism.

\section{3.- Recent development in Mediterranean and Middle East countries.}

The regions of North Africa and Middle East countries have a wealth of heritage, a climate conducive to tourism and a range of leisure resources that should provide a comparative and competitive advantage to its tourism industry. According to Lanquar (2011), the previous two decades antes de la revolución árabe y los acontecimientos posteriores, the 11 countries of the Southern Mediterranean (MED11) (Algeria, Egypt, Israel, Jordan, Lebanon, Libya, Morocco, Palestinian Territory, Syria, Tunisia and Turkey) have recorded the highest growth rates in inbound world tourism. International tourist arrivals in MED11 rose by 365\% between 1990 and 2010 compared to $214 \%$ 
globally. During the same period, international tourism receipts in the MED11 in constant dollars of 2000 , increased by $384 \%$, twice as much as the increase of the entire world for the same period. The increase was particularly strong in Egypt and Turkey.

However, according to UNWTO (2015), in 2014, they attracted only $6.2 \%$ of international tourism arrivals and 4.8 of receipts, what means that region is far from fully capitalizing the potential that it holds. En relación a ello, numerous sectoral reports agree that South Mediterranean tourism has structural defects, principally the low diversity of the tourism offer con una elevada dependencia de Europa, which on average account for $60 \%$ of international arrivals. Also, it is characterized by a strong seasonality (that hinders the development of tourism industries), the absence of differentiation and products that are proving to be increasingly out of step with the evolution of international tourism which all constitute problematic features (Weigert, 2012).

The causes of these defects are rooted in the tourism development model chosen for the region. It has taken the shape of self-contained enclaves in the form of coastal resort complexes, all-inclusive package tours, or urban hotel complexes providing a range of on-site services. Establishments compete on price (rather on quality). As pointed out by many authors, this kind of development limits the forms of social and economic interaction between tourists and host societies and reduces the contribution of tourist spending to the development of the local economy. Likewise, the polarization of tourism activity in the coastal areas has aggravated the territorial development imbalances to the detriment of the inland areas (Weigert, 2012).

Tourism development in the Arab region is highly unbalanced: while countries such as Algeria or Libya are closed to tourism, other enclaves such as Tunisia, Morocco, Egypt and Jordan see tourism as an strategic sector con el que diversificar sus economías más 
allá del petróleo (Weigert, 2012; Tang and Abosedra, 2014) (see Table 1). Tourism receipts account for over $20 \%$ of GDP in Lebanon, $12 \%$ in Jordan and between $5 \%$ and 8\% of GDP in Morocco, Tunisia and Egypt, (Deutsche Bank Research, 2013), de ahí que el impacto de la actual crisis política adquiera tanta importancia para estos países.

Table 1 about here

Tal y como se ha mencionado antes, it is need to manage crises caused by political instability, but controlling these kind of events and their effects on tourism is not completely effective. Feichtinger, Hartl, Kort \& Novak (2001) suggest that sometimes a cyclical behavior is observed. With regard to the effects of the 9/11 attacks, the tourism industry in the Arab World responded to the negative publicity caused by terrorist attacks with within-region promotions and marketing tactics. In addition, the potential of developing "Islamic tourism" received more serious discussion (Al-Hamarneh \& Steiner, 2004).

Contrary to some assumptions, the universal collapse of the tourism industry in Arab countries that was predicted after the attacks did not take place (Al-Hamarneh \& Steiner, 2004). The 9/11 attacks and the "global war on terror" resulted in a decline in tourism in the Middle East region: over the course of 2001, worldwide arrivals declined by $0.5 \%$, while across the Arab Middle East tourist arrivals fell by $1.3 \%$. This decline followed two years of double-digit growth and high expectations for the sector across the region. However, in 2004, most of the region quickly rebounded from the $15 \%$ drop in arrivals for the second quarter of 2003 with a $17 \%$ increase (Hazbun, 2006).

Sin embargo, los recientes acontecimientos que están teniendo lugar en Oriente Próximo muestran síntomas mucho más preocupantes, ya que la crisis política se está viviendo in situ. La inestabilidad que siguió a the Arab Spring uprising had a significant 
impact on economic and tourism activity in North Africa. According to Deutsche Bank Research (2013), average real GDP growth in the region fell from $4.2 \%$ in 2010 to $2.2 \%$ in 2011, its lowest level in a decade. The slowdown affected hardest in countries such as Libya, Tunisia, Egypt, Syria and Yemen, protagonistas de los cambios politicos más importantes de la región. Only Morocco maintained a low growth in its GDP during 2011. In 2013 the GDP growth rates remained below the pre-revolutionary levels.

En relación al tuirsmo, the number of tourist arrivals in the five main destinations in the region -Egypt, Tunisia, Morocco, Jordan and Lebanon - fell by a quarter, from 20 million in H1 2010 to 15 million in H1 2011, especialmente in Egypt and Tunisia, by about $40 \%$ each. A pesar de los problemas de competitividad de la zona remarcados antes, en los últimos años la verdadera responsable de la crisis y la ausencia de eficiencia turística es la inestabilidad política, tal y como destaca Morakabati (2013).

La reducción de visitantes y gasto turístico en los países árabes coincide con resultados turísticos muy positivos en otros países Mediterráneos como Grecia, Turquía y especialmente España (Figures 1), que cada año supera sus cifras. Although tourism is a very resilient industry, political instability (including wars, terrorism or crime) usually has a negative impact on the tourism flows of directly affected countries. Neighboring countries can be positively or negatively affected depending on the predominance of a spillover or substitution effect. As a result, losers and winners emerge as a consequence of these events.

Apart from this short-term effect on tourist arrivals, long-term effects derived from investment-flows are observed. For example, the presence of Spanish international hotel chains in North African countries (see Table 2) has been seriously affected by instability in the area. 
Figure 1 about here.

Table 2 about here

Dados estos precedentes y la evolución turística en la region árabe, se hace neceario analizar el verdadero impacto en términos de flujos turísticos de todos los acontecimientos que sucedieron a la Primavera Árabe.

4.-Methodology and data.

As explained in the introduction, to determine the impact of the uprisings on tourist arrivals in selected countries, we have used a Bayesian Structural Time-Series Models framework proposed by Brodersen, et al. (2015) and implemented in the CausalImpact R-package. (R-Core-Team, 2015).

Structural time-series models can be defined in terms of a pair of equations:

$$
\begin{aligned}
y_{t} & =Z_{t}^{T} \alpha_{t}+\varepsilon_{t}(1) \\
\alpha_{t+1} & =T_{t} \alpha_{t}+R_{t} \eta_{t}
\end{aligned}
$$

Where $y_{t}$ is a scalar observation, $\mathrm{Z}_{\mathrm{t}}$ a d-dimensional output vector, $\mathrm{T}_{\mathrm{t}}$ is $d x d$ transition matrix, $\mathrm{R}_{\mathrm{t}}$ is a $d x q$ control matrix, $\varepsilon_{t} \sim N\left(0, \sigma_{t}^{2}\right)$ is a scalar observation error with noise variance $\sigma_{\mathrm{t}}$ and $\eta_{t} \sim N\left(0, Q_{t}\right)$ is a $q$-dimensional system error with a $q \times q$ statediffusion matrix $\mathrm{Q}_{\mathrm{t}}$ where $q \leq d$ that are independent of all other unknowns. Equation (1) is the observation equation: it links the observed data $y_{t}$ to a latent evolution of the state vector $\alpha_{t}$. Equation (2) is the state equation; it governs the evolution of the state vector $\alpha_{t}$ through time.

Structural time-series models are flexible - a very class of models, including all autoregressive integrated moving average models ARIMA models can be written in the state-space form given by (1) and (2) - and modular - the latent states as well as the 
associated model matrices $\mathrm{Z}_{t}, \mathrm{~T}_{\mathrm{t}}, \mathrm{R}_{\mathrm{t}}$ and $\mathrm{Q}_{\mathrm{t}}$ can be assembled from a library of component sub-models to capture important features of the data as trend, seasonality or effects of holidays, etc. - (Brodersen, et al., 2015).

The most important state component of this approach is a regression component that allows to create counterfactual predictions by constructing a synthetic control based on a combination of markets that were not treated (i.e. a crucial assumption of this approach is that covariates -countries used as controls - are unaffected, in our case, by the effects of Arab uprisings). This represents an advantage with respect to intervention analysis using solely ARIMA models due to that last methodology only takes into account the evolution of the target country under consideration before and after the event without these controls. However, esto no significa que los modelos ARIMA no sean útiles en este contexto, pues de hecho ARIMA estimations are also performed in this paper in order to pre-test the adequacy of a set of potential control countries and to check the robustness of the obtained results.

With regard to this regression component, static or dynamic regression could be used to estimate the impact of an event. When the relationship between the controls and treated units has been stable in the past, static coefficients are more suitable. Meanwhile, dynamic coefficients are useful when the linear relationship between treated metrics and controls is believed to change over time (Brodersen, et al. 2015).

Regarding to inference and estimations, a Bayesian approach is used. In a nutshell causal impact is estimated by subtracting the predicted response obtained from a semiparametric Bayesian posterior estimation and the observed response during the post-intervention (Brodersen, et al. 2015). 
Let $\theta$ generally denote the set of all model parameters and let $\alpha=\left(\alpha_{1}, \ldots, \alpha_{m}\right)$ denote the full state sequence. First, a prior distribution of the parameters $p(\theta)$ as well as a distribution $p\left(\alpha_{0} \mid \theta\right)$ on the initial state values is established using the Gamma distribution and a spike-and-slab prior over coefficients when many potential controls exists.

Second, posterior distribution of the counterfactual time series given the value of the target series in the pre-intervention period is constructed along with the values of the controls in the post-intervention period. To this end, draws of the model parameters $\theta$ and the state vector $\alpha$ are simulated for the training period using Gibbs sampler and the observed data $y_{1: n}$. The sampler simulates a sequence $(\theta, \alpha)^{(1)},(\theta, \alpha)^{(2)}, \ldots$ from a Markov chain whose stationary distribution is $p\left(\theta \mid y_{1: n}, \alpha\right)$. The sampler alternates between a data-augmentation step that simulates from $p\left(\alpha \mid y_{1: n}, \theta\right)$ and a parametersimulation step that simulates from $p\left(\theta \mid y_{1: n}, \alpha\right)$.

Third, posterior simulations are performed from the posterior predictive distribution $p\left(\tilde{y}_{n+1: m} \mid y_{1: n}, x_{1: m}\right)$ over the counterfactual time series $\tilde{y}_{n+1: m}$ given the observed preintervention activity $y_{1: n}$. The posterior predictive density is defined as a coherent (joint) distribution over all counterfactual data points, rather than as a collection of pointwise univariate distributions.

Finally, samples from the posterior predictive distribution over the counterfactual activity can be used to obtain samples from the posterior causal effect. For each draw $\tau$ and for each time point $t=n+1, \ldots, m$, we set $\phi_{t}^{(\tau:)}:=y_{t}-\tilde{y}_{t}^{(\tau)}$, yielding samples from the approximate posterior predictive density of the effect attributes to the intervention. In this paper we analyze the impact of the Arab uprisings on tourism destinations using a two-step methodology (see Figure 2) and annual data provided by the World Travel 
Organization (several Compendiums to complete the period 1980-1995 have been used) and the World Bank (2015) for the period 1980-2014 (35 annual observations).

Figure 2 about here

In the first step, to establish the set of suitable countries used for control purposes in the causal analysis (i.e. to introduce their international tourist arrivals in the regression component of the models as benchmark), we performed an analysis of single time series using ARIMA methods. This let us to check if countries appear to be affected by Arab uprisings or not. Any country with appearance to be affected by events are discarded as potential control in the second step.

To perform ARIMA estimations, we used the Hyndman \& Khandakar (2008) algorithm implemented in the forecast R-package (Hyndman, 2015). Specifically, we split each series into two periods. Data until 2009 was used to forecast the individual behavior of each country for the period 2010-2014. Then, we compared predicted and real values of the series beyond 2010. Countries where forecasts and the reality in the period 20102014 are more closely matched are suspected to be less affected by uprisings and are considered as suitable to be used as controls in the second step where impact by causal analysis is estimated.

The potential countries initially considered as controls were France, Italy, Brazil, Mexico, Dominican Republic and the entire World (see Figure 3). World evolution was used as a reflection of the industry as a whole. Brazil, Mexico and Dominican Republican were considered because they compete in the same product (sun and beach) as some of the analyzed destinations with a predominance of all-inclusive resorts, such as Tunisia, Egypt or Turkey and have not been affected by the uprisings. Finally, France and Italy were considered because they are also Mediterranean destinations, have 
similar degrees of maturity as Spain or Greece, and appear to have been less affected by the Arab uprisings than other Mediterranean countries.

In the second step, we estimated the impact of the uprisings on international tourist arrivals in Tunisia, Egypt, Morocco, Greece, Turkey and Spain controlling for the countries identified in the first step. As explained before, the event is located in 2010, thus we split the sample in two periods. Data up until 2009 was used to create the counterfactual scenario and data between 2010 and 2014 was used to estimate the impact. In line with Brodersen et al. (2015), we used the static regression option to reduce overfitting problems. The next section describes the econometric estimations.

Figure 3 about here

\section{5.-Econometric analysis and results}

Figure 4 and 5 represent Step 1 of our methodology. Figure 4 shows the estimated ARIMA model for each country using the data until 2009. The dashed line represents the forecast and the solid line represents the realization of the series during the period 2010-2014. As we can see, in principle the uprisings have had a negative effect in Tunisia, Egypt and Turkey (realization lines below their self-predictions), and a positive effect in the rest of the analyzed countries. In Morocco, the two lines are practically matched for the whole period with 2012 being an inflection point. In Spain, a change in trend is also observed in 2012 when the distance between two lines increases. Greece, despite its economic problems, also experienced a sharp increase in the distance between the predicted and realized values of the series after 2012 .

Regarding these last two countries, it should be noted that especially Greece, went through internal devaluations during this period as an imposition of the Troika. Thus, probably part of the attractiveness of Greek and in a lesser extent Spanish tourism at the 
time comes from the increase in competitiveness via decreased costs and not only from the uprisings in competitors.

Figure 4 about here

Table 3 summarizes the impact on each Mediterranean country analyzed based on pointwise forecasts and realizations of each series for the $2010-2014$ period using the ARIMA models. We can see that Egypt (-23.81\%) and Tunisia (-21.24\%) are the countries most negatively affected by the uprisings. Turkey $(-14.39 \%)$ also experienced a decline with respect to its expectations. Conversely, Greece $(+8.89 \%)$, Spain $(+5.95 \%)$ and Morocco (+4.14\%) benefited from the instability.

With regard to the potential controls (Figure 5), France and Italy seem to be the most suitable countries because the realization of their series between 2010 and 2014 perfectly match their expectations for this period. Mexico, except for years 2013 and 2014, also exhibits good behavior. Conversely, Brazil, Dominican Republic and the World as a whole outperform their expectations.

Table 3 about here

Figure 5 about here

After establishing the set of potential countries as controls, we performed the impact analysis. Table 4 summarizes the results obtained. The first column of the table shows the ARIMA estimations (shown in the last two columns of Table 3) to facilitate the comparison between the results obtained using the two methodologies. Each cell of the columns 2 to 5 of the table contains the absolute cumulative impact during the whole period 2010-2014 (first digit), the relative cumulative impact (middle digit) and the 95 per cent posterior confidence interval for the relative impact of the whole period (in parentheses). 
The results confirm that the set of countries used as a control is crucial for impact estimations. In general, in terms of the affected countries, this methodology captures the decline of arrivals in Tunisia better than in Egypt. With respect to the unaffected countries, the methodology captures better the positive impact of the uprisings in Morocco and Turkey than in Spain and Greece.

Focusing on the directly affected countries, comparing columns 1 and 2 of Table 4, we can see that the Brodersen et al (2015) methodology controlling for the World evolution results produces a negative impact for Tunisia $(-27 \%)$ that is higher than that estimated by its ARIMA model (-21.24\%). A higher negative impact is also obtained controlling for the World, Mexico and Dominican Republic (column 3). In both cases, the impact is significant (the zero does not belong in the confidence interval). Conversely, the impact for Egypt (-6.5\% in column 2 and $-15 \%$ in column 3$)$ is lower than its ARIMA model ($23.81 \%)$ and lacks statistical significance.

With respect to the control countries representing the evolution of the Mediterranean area (France and Italy), for Tunisia we obtained a lower impact (-12\% in column 4$)$ than in the previous cases and with respect to its ARIMA model, and no credible positive effect is obtained for Egypt. But in both cases the results obtained lack statistical significance.

Finally, the last column shows the estimated impact using a combination of the evolution of the sand and beach resort destinations (reflected by Mexico and Dominican Republic) and the evolution of the Mediterranean area represented by France and Italy. In this case, a significant negative impact $(-21 \%)$ matching the results obtained with its ARIMA model is observed for Tunisia. Conversely, in the case of Egypt, a lower ($12 \%)$ and not significant impact is obtained. 
Table 4 about here

Figure 6 and 7 show the impact on Tunisia and Egypt respectively controlling for the World tourism evolution. The first panel shows the data and a counterfactual prediction for the post-treatment period. The second panel shows the difference between observed data and counterfactual predictions. This is the pointwise causal effect, as estimated by the model. The third panel adds up the pointwise contributions from the second panel, resulting in a plot of the cumulative effect of the intervention (Brodersen et al, 2015).

Figure 6 and 7 about here

The results for the indirectly affected countries are less clear than those for the directly affected ones. For Morocco the impact using the Brodersen et al. (2015) methodology is, in all cases (ranging from +20 in column 3 to +48 per cent in column 4 ), higher than estimated by its ARIMA model. This positive impact is statistically significant regardless of the countries introduced in the regressions. For Turkey, contrary to the negative impact obtained with its ARIMA model, a positive impact ranging from $+27 \%$ in column 1 to $+50 \%$ in column 4 (the $+15 \%$ in column 3 lacks significance) of the uprisings is now estimated.

Meanwhile, the results for countries located on the northern shores of the Mediterranean are even more confusing. In fact, no significant impact is estimated for Greece and Spain in the whole Table. In both countries, the only estimation that results in a positive impact of the Arab uprisings on their tourism flows is obtained using France and Italy as 
controls (column 4). But this positive impact lacks statistical significance. Moreover, controlling for the World evolution in the case of Spain results in a statically significant negative $(-10 \%)$ impact of the uprisings for this country, which is highly suspicious. Likewise, all estimations for both countries in Table 4 are very different to those obtained by their ARIMA models.

The unexpected negative impact using the World as a comparison framework for Spain and Greece could be attributable to the higher degree of maturity of these countries in the international tourism market and the impossibility of them reaching the growth rates of other emerging destinations. The declining trend in their shares of the international tourism market would be proof of this behavior. In this sense, we think that the most realistic impact for both countries is that obtained when France and Italy are included in the regression, as reflected in column 4 of Table 4 . However, as previously mentioned, the positive impact estimated in this case lacks statistical significance.

Another plausible explanation for the lack of a positive and statistically significant impact on Spain and Greece could be the concurrence of the Arab events with the profound economic crises in these two countries, which could be acting as a confounding factor, affecting the result of estimations. But these two effects cannot be separated using the Brodersen et al. (2015) procedure.

\section{6.-Conclusion.}

In general the Arab Spring opens a debate on whether the nascent democracy it has spawned at least in Tunisia and Egypt, and the reforms it has induced elsewhere, might reverse previous vicious circle to virtuous cycles facilitating industrialization. Following Springbor (2011), the key question is: Might the Arab Spring convert the 
vicious cycle into a virtuous cycle of interaction between economics and politics in Arab countries?

Observando el nacimiento de la Primavera Árabe, one of the critical economic lessons of the last decade has been that it is not growth per se but the type of growth that matters (Malik \& Awadallah, 2013). The hoped-for trickle-down effect of such growth either failed to materialize or was not sufficiently robust to prevent the widespread and deepening disillusionment and unrest (Hassan, 2011). The crisis of the Arab Spring revealed the obsolescence of the tourism development model in the region, based on both social authoritarianism and a disconnected territorial offer, where tourists do not encounter the socioeconomic and political conditions experienced by the local populations. For these reasons, authors such as Weigert (2012) suggest that this kind of tourism probably will not survive the process of democratization triggered by the Arab revolutions, giving rise to positive perspectives for the advent of a better tourism development based on sustainable principles.

In this paper we have analyzed the effects of the Arab uprisings y los acontecimientos posteriores on the tourism destinations along the Mediterranean coastline. International tourist arrivals in Tunisia, Egypt, Morocco, Turkey, Spain and Greece have been modeled using ARIMA methods and a Bayesian Structural Time-Series procedure proposed by Brodersen et al (2015).

Econometric estimations performed in section 4 have shown that the uprisings have had a clear impact on the international tourism flows in directly affected countries. In Tunisia, both the ARIMA and Brodersen et al. (2015) procedures lead to the same conclusion: a negative impact in terms of tourism of Arab uprisings in this country. In the case of Egypt, although the estimations mostly show a negative point-estimate of the impact of the events, the result is less clear as the estimations lack statistical 
significance. In any case, despite the potential doubts about Egypt, it seems clear that both countries would be losers in terms of a reduction in their tourism competitiveness provoked by the uprisings. Otros perdedores serían claramente Siria y Libia -donde las situaciones de guerra han provocado que el último dato reportado haga referencia a 2011 y 2008 respectivamente-, y en menor medida Líbano y Jordania -que también viene experimentando estancamientos o reducciones en el número de llegadas desde los inicios de los eventos-.

With regard to potential winners, Morocco and Turkey appear to be the countries that have most benefited from the Arab uprisings. In both countries, the Brodersen et al. (2015) methodology leads to the conclusion that the uprisings have had a positive impact on tourism competitiveness. In the case of Turkey, the result of the aforementioned methodology contradict those obtained using the preferred ARIMA model. But results in Table 4 for this country are robust irrespective of the countries used as controls. As a practical implication of this result, it is worth noting that both countries belong to the North African region or near it, thus we could conclude that the potential spillover effect, negatively affecting neighboring countries has not been observed during the Arab uprisings. Conversely, a deviation effect appears to be clearer.

Israel - que no ha sido analizado en este artículo- también parece ser otro de los ganadores en este contexto, habida cuenta los resultados positivos que viene observando en términos de llegadas internacionales. En cualquier caso, It would be interesting to continue this study analyzing the effects on tourism in non-Mediterranean neighboring countries, especially the United Arab Emirates.

The effects of the uprisings on Spain and Greece are less clear and a comparison with countries in the same stage of tourism development is needed to obtain a positive impact of the uprisings on their tourism flows. Moreover, when obtained, the positive 
impact is not significant from a statistical viewpoint. This does not mean that Spain and Greece have not benefited from the Arab uprisings. As we can see in column 4 of Table 4, the upper limit of confidence intervals for both countries suggests that until a relative positive impact of +17 per cent for the case of Greece and +14 per cent for the case of Spain there is compatibility with the available data. In this sense, it is well-known that some Spanish tourism destinations such as the Balearic and Canary Islands have received many tourists diverted by tour-operators from Tunisia and Egypt. However, the Brodersen et al (2015) methodology using the aggregate data for whole countries, which has been done in this paper, has not been able to capture the deviation effect on these countries with more clarity. This represents one of the limitations of this study.

Other limitations of this paper are that it focuses only on tourism arrivals and the limited set of countries used as controls. Probably, the use of a broader range of countries could generate better estimations of the impact and narrow confidence intervals. International tourism arrivals data from 1995 to 2013 are available for many countries in the World Bank database. So, it would be possible to reproduce and refine this study by introducing a broader set of countries in the regressions. Also, analyzing a broader set of variables such as tourism receipts or direct investment flows could improve the perception of the impact of uprisings on tourism industry. Both of these tasks are recommended for future research.

Furthermore, another line of future research would be to check the robustness of the analysis performed using other techniques within the time series framework or any other econometric procedure. Likewise, apart from this kind quantitative analysis of the impacts of the uprisings, a qualitative analysis of the consequences of the uprisings is needed. As reflected in the introduction and literature review, some authors consider that the Arab Spring has represented a deep change in Arab societies, opening up 
opportunities to change the tourism development model of the affected countries towards a new tourism based on more sustainable principles. These qualitative changes also represent a relevant line of research question per se. 
Bibliography:

Alexander, Y. (2012). Special Update Report. Terrorism in North, West \& Central Africa: From 9/11 to the Arab Spring. International Center for Terrorism Studies. Arlington, USA.

Al-Hamarneh, A, \& Steiner, C. (2004). Islamic Tourism: Rethinking the Strategies of Tourism Development in the Arab World After September 11, 2001. Comparative Studies of South Asia, Africa and the Middle East, 24:173-182.

Ansani, A. \& Daniele, V. (2012). About a revolution: The economic motivations of the Arab Spring. International Journal of Development and Conflict, 2 (3): 1250013 (24 pages).

Avraham, E. (2015). Destination image repair during crisis: Attracting tourism during the Arab Spring uprisings. Tourism Management, 47, 224-232.

Beck, L. (2014). The Influence Events of the Arab Spring had on Tourism in Middle Eastern and North Africa States. The Cases of Egypt and Tunisia as Countries which had part in the Arab Spring compared with Morocco and the UAE as Countries which were not part of the Arab Spring. Master Thesis. Università della Svizzera Italiana.

Brodersen, K., Galluser, F., Koehler, J., Remy, N. \& Scott, S. (2015). Inferring Causal Impact Using Bayesian Structural Time-Series Models. The Annals of Applied Statistics, 9 (1):247-274.

Brunt, P. \& Hambly, Z. (1999). Tourism and Crime: A Research Agenda. Crime Prevention and Community Safety: An International Journal, 1: 15-26.

Buckley, P. \& Klemm, M. (1993). The Decline of Tourism in Northern Ireland: The Causes. Tourism Management, 14:184-194

Conant, J., Clarck, T., Burnett, J. \& Zank, G. (1988). Terrorism and Travel Managing the Unmanageable. Journal of Travel Research, 26(4): 16-20.

D'Amore, L \& Anuza, R. (1986). International Terrorism: Implications and Challenge for Global Tourism. Business Quarterly, 11:20-29.

Deutsche Bank Research (2013). Two years of Arab Spring. Where are we now? What's next? Deutsche Bank Research Report Current Issues Emerging Markets. Frankfut am Main. Germany.

Drakos, K. \& Kutan, A. (2003). Regional Effects of Terrorism on Tourism in Three Mediterranean Countries. Journal of Conflict Resolution, 47(5):621-641.

Dwyer, L. \& Kim, C. (2003).Destination competitiveness: determinants and indicators. Current Issues in Tourism, 6 (5), 369-414.

Enders, W. \& Sandler, T. (1991). Causality Between Transnational Terrorism and Tourism: The Case of Spain. Terrorism, 14:49-58. 
Enders, W., Sandler, T. \& Parise, G. (1992). An Econometric Analysis of the Impact of Terrorism on Tourism. Kyklos, 45: 531-554.

Enders, W. \& Sandler, T. (1995). Terrorism: Theory and applications. In T. Sandler and K. Hartley (eds). Handbook of Defense Economics. Vol. 1 pp: 213-249. Elsevier.

Feichtinger, G., Hartl, R., Kort, P. \& Novak, A. (2001). Terrorism Control in the Tourism Industry. Journal of Optimization Theory and Applications, 108 (2):283-296.

Fielding, D. \& Shortland, A. (2011). How do tourists react to political violence? An empirical analysis of tourism in Egypt. Defense and Pease Economics, 22(2):217-243.

Fisher, K. (2003). Terrorism \& Tourism. Leisure Management, 23 (2):36-38.

Frey, B. \& Lüchinger, S. (2009). Tourismus und Terrorismus aus ökonomischer Sicht. Zeitschrift für Tourismuswissenschaft, 1(1):63-73.

Gartner, W. \& Shen, J. (1992). The Impact of Tiananmen Square on China's Tourism Image. Journal of Travel Research, 30 (4): 47-52

Hall, C. (2010). Crisis events in tourism: Subjects of crisis in tourism. Current Issues in Tourism, 13 (5): 401-417

Hall, C. \& O’Sullivan, V. (1996). Tourism, Political Instability and Violence. In A. Pizam and Y. Mansfeld (eds). Tourism, Crime and International Security Issues, pp: 187-202- New York. Wiley.

Hassan, H. (2011). The Economic Prospects of the 'Arab Spring': A Bumpy Road Ahead. CDPR Development Viewpoint, 63: 1-2

Hazbun, W. (2006). Explaining the Arab Middle East Tourism Paradox. The Arab Geographer, 9 (3):201-214.

Henderson, J.C. (1999b). Southeast Asian tourism and the Financial Crisis: Indonesia and Thailand Compared. Current Issues in Tourism, 2 (4): 294-303.

Hollier, R. (1991). Conflict in the Gulf: Response of the Tourism Industry: Tourism Management, 12:2-4.

Hosteltur (2010). Ranking de cadenas hoteleras 2010. www.hosteltur.com

Hosteltur (2014). Ranking de cadenas hoteleras 2014. www.hosteltur.com

Hurley, J. (1988). The Hotels of Rome: Meeting the Marketing Challenge of Terrorism. The Cornell Quarterly, 29(1): 71-79.

Hyndman, R (2015). forecast: Forecasting functions for time series and linear models. R package version 6.1, http://github.com/robjhyndman/forecast

Hyndman, R \& Khandakar, Y. (2008). Automatic time series forecasting: the forecast package for R. Journal of Statistical Software, 26(3): 1-22.

Korstanje, M. \& Clayton, A. (2012). Tourism and terrorism: conflicts and commonalities. Worldwide Hospitality and Tourism Themes, 4 (1): 8-25. 
Lanquar, R. (2011). Tourism in the Mediterranean: Scenarios up to 2030. MEDPRO Report No. 1. www.medpro-foresight.eu.

Leep, A. \& Gibson, H. (2003). Tourist Roles, Perceived Risk and International Tourism. Annals of Tourism Research, 30: 606-624.

Malik, A., \& Awadallah, B. (2013). The economics of the Arab Spring. World Development, 45: 296-313.

Mansfeld, Y. (1996). Wars, Tourism and the "Middle East" Factor. In A. Pizal \& Y. Mansfeld. Tourism, crime and international security issues. John Wiley. New York.

Mansfeld, Y. \& Kliot, N. (1996). The Tourism Industry in the Partitioned Island of Cyprus. In A. Pizam and Y. Mansfeld (eds). Tourism, Crime and International Security Issues, pp: 187-202- New York. Wiley.

Mansfeld, Y., \& Winckler, O. (2015). Can this be spring? Assessing the impact of the "Arab Spring" on the Arab tourism industry. Turizam: znanstveno-stručni časopis, 63(2), 205-223.

Mihalic, T. (1996). Tourism and Warfare. The Case of Slovenia. In A. Pizam and Y. Mansfeld (eds). Tourism, Crime and International Security Issues, pp: 232-246- New York. Wiley.

Neumayer, E. (2004). The Impact of political violence on tourism - Dynamic crossnational estimation. Journal of Conflict Resolution, 48:259-281.

Morakabati, Y. (2013). Tourism in the Middle East: Conflicts, Crises and Economic Diversification , Some Critical Issues. International Journal of Tourism Research, 15 (4):375-387.

Paraskevas, A. \& Arendell, B. (2007). A strategic framework for terrorism prevention and mitigation in tourism destinations. Tourism Management, 28 (6):1560-1573.

Perles, J., Ramón, A., Rubia, A. \& Moreno, L. (2013). Economic crisis and tourism competitiveness in Spain: permanent effects or transitory shocks? Current Issues in Tourism, in press. DOI 10.1080/13683500.2013.849666

Pizam, A. (1999). A comprehensive approach to classifying acts of crime and violence at tourism destinations. Journal of Travel Research, 38:5-12.

Pizam, A. \& Smith, G. (2000). Tourism and terrorism: a quantitative analysis of major terrorist acts and their impact on tourism destinations. Tourism Economics, 6 (2):123138.

Raza, S. \& Jawaid, S. (2013). Terrorism and Tourism: A conjunction and ramification in Pakistan. Economic Modelling, 33:65-70.

R Core Team (2015). R: A language and environment for statistical computing. R Foundation for Statistical Computing, Vienna, Austria. https://www.R-project.org/.

Ritcher, L. (1980). The Political Uses of Tourism: A Philippine Case Study. The Journal of Developing Areas, 14:237-257. 
Ritcher, L. \& Waugh, W. (1986). Terrorism and Tourism as Logical Companions. Tourism Management, 7 (4):230-238.

Ryan, C. (1991). Tourism, Terrorism and Violence: the risks of wider world travel. Research Institute for the Study of Conflict and Terrorism. London.

Schwartz, R. (1991). Travelers Under Fire: Tourists in the Tibetan Uprising. Annals of Tourism Research, 18(4):588-604.

Scott, R. (1988). Managing Crisis in Tourism: A Case Study of Fiji. Travel and Tourism Analyst, 6: 57-71.

Singh, R. (2013). Terrorism and Tourism. International Journal of Advanced Research in Management and Social Sciences, 2 (11):187-198.

Sloboda, B. (2003). Assesing the effects of terrorism on tourism by use of time series methods. Tourism Economics, 9 (2): 179-192.

Smith, V. (1996). War and Its Tourist Attractions. In A. Pizam and Y. Mansfeld (eds). Tourism, Crime and International Security Issues, pp: 215-227- New York. Wiley.

Sönmez, S. \& Graefe, A. (1998). Influence of Terrorism Risk on Foreign Tourism Decisions. Annals of Tourism Research, 25:112-144.

Sönmez S., Apostolopoulos, Y. \& Tarlow, P. (1999). Tourism in Crisis: Managing the Effects of Terrorism. Journal of Travel Research, 38(1):13-18

Sönmez, S., Backman, S. \& Allen, L. (1994). Managing Tourism Crises: A Guidebook. Clemson, SC: Clemson University.

Springborg, R. (2011). The Political Economy of the Arab Spring. Mediterranean Politics, 16 (3):427-433.

Tang, C. F. \& Abosedra, S. (2014). The impacts of tourism, energy consumption and political instability on economic growth in the MENA countries. Energy Policy, (68), 458-464.

Teye, V. (1986). Liberation Wars and Tourism Development in Africa: The Case of Zambia. Annals of Tourism Research, 13:589-608.

Thompson, A. (2011). Terrorism and tourism in developed versus developing countries. Tourism Economics, 17 (3):693-700.

UNWTO World Tourism Organization (2015). Tourism Highlights 2015 Edition. Madrid,

Wahab, S. (1996). Tourism development in Egypt: Competitive Strategies and Implications. Progress in Tourism and Hospitality Research, 2: 351-364.

Wall, G. (1996). Terrorism and Tourism: An Overview and an Irish Example. Tourism, crime and international security issues. In A. Pizal \& Y. Mansfeld. Tourism, crime and international security issues. John Wiley. New York. 
Weigert, M. (2012). The Challenges of Tourism in the Mediterranean Region. 209. IEMed Mediterranean Yearbook. Panorama. París.

World Bank (2015). World Development Indicators. www.data.worldbank.org

World Travel and Tourism Council WTTC (2014). Travel and Tourism Economic Impact, several country reports. http://www.wttc.org

World Travel and Tourism Council WTTC (2015). Travel and Tourism Economic Impact, several country reports. http://www.wttc.org

Yang, Y. \& Wong, K. (2012). A Spatial Econometric Approach to Model Spillover Effects in Tourism Flows. Journal of Travel Research, 51:768-778.

Yaya, M. (2008). Terrorism and Tourism: The Case of Turkey. Defence and Peace Economics, 20 (6): 477-497.

Zheng, G. \& Martin, T. (1992). Terrorism, Seasonality, and International Tourist Arrival in Central Florida: An Empirical Analysis. Journal of Travel and Tourism Marketing, 1 (1):3-15 
Figures and Tables

Figure 1: International Tourism Arrivals Mediterranean countries.

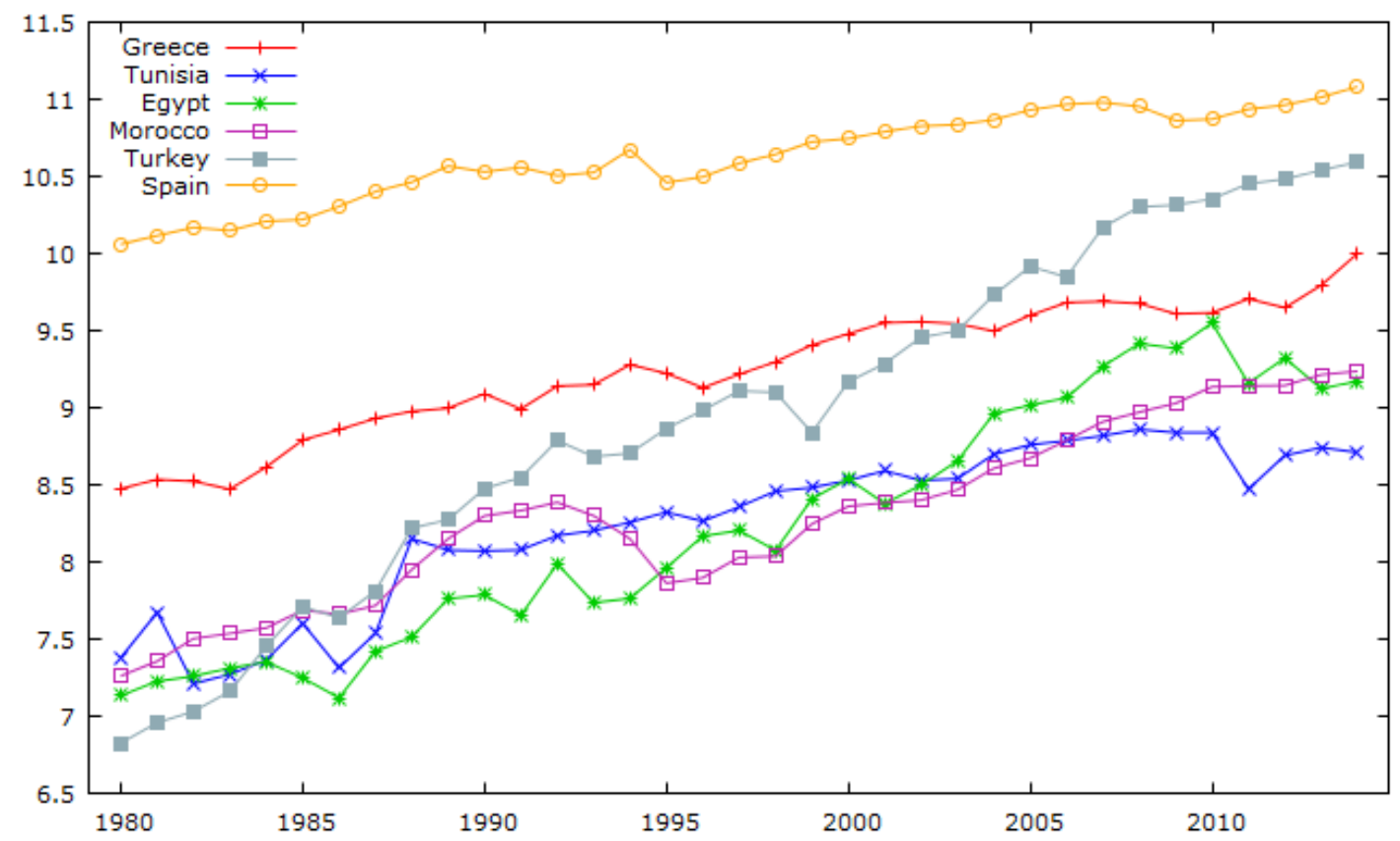

Source: World Bank Development Indicators and WTO. Natural logarithms. 
Figure 2: Two-step methodology to estimate the impact of the Arab Spring.

Step 1: Determine countries to be used as control

Hyndman \& Khandakar (2008)

1.1.-Estimate ARIMA model for each series using data from 1980 to 2009

1.2-Forecast ARIMA model for the period 2010-2014

1.3.-Compare predictions and the real behavior of the series

1.4.-Countries where predictions and real behavior are most closely matched are considered as suitable controls

Step 2: Determine the impact of the Arab Spring Event (Brodersen et al., 2015)

2.1-Fix the event in 2010

2.2.-Estimate the counterfactual using international tourists arrivals data from 1980 to 2009 for the target country and the countries selected as control in the regression component.

2.3-Estimate the impact by subtracting the real behavior of the series from 2010 to 2014 from the counterfactual scenario for this period. 
Figure 3: International Tourist Arrivals 2010-2014. Potential countries used as controls in the impact analysis.

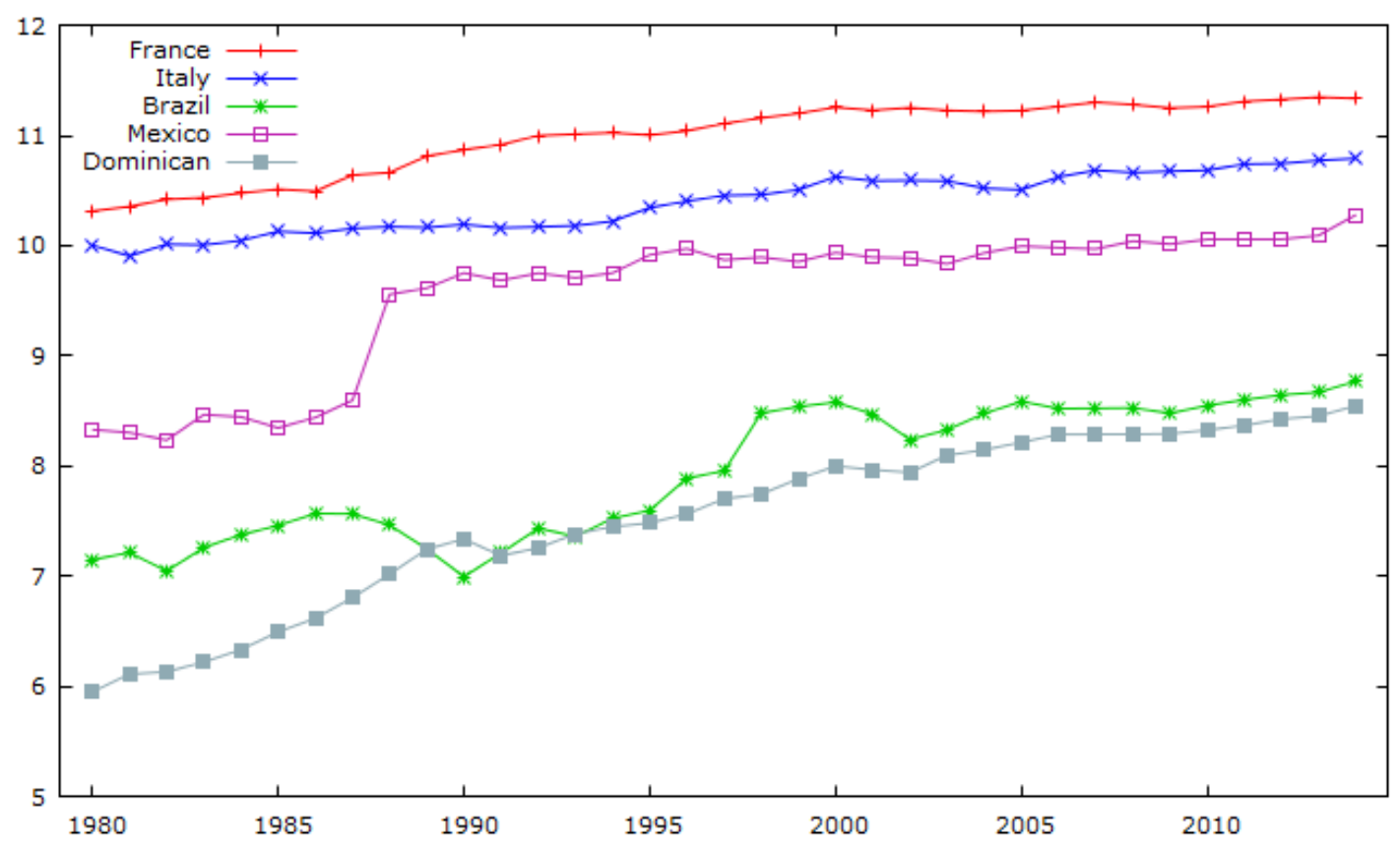

Source: World Bank Development Indicators and WTO. Natural logarithms. 
Figure 4: Analyzed Countries, Predicted and Real International Tourist Arrivals 20102014. ARIMA models.
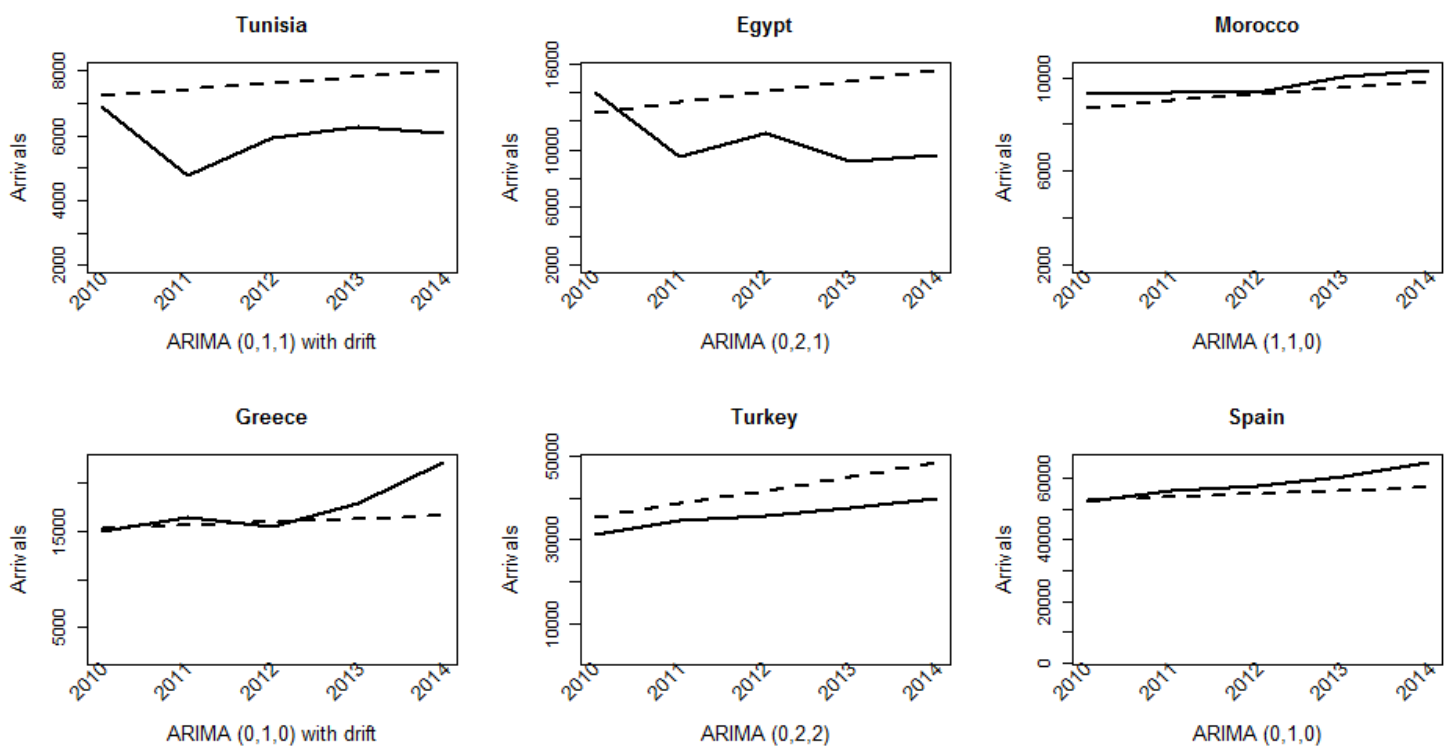

Authors own elaboration. Tourists x 1000 
Figure 5: Potential Controls, Predicted and Real International Tourist Arrivals 20102014. ARIMA models.
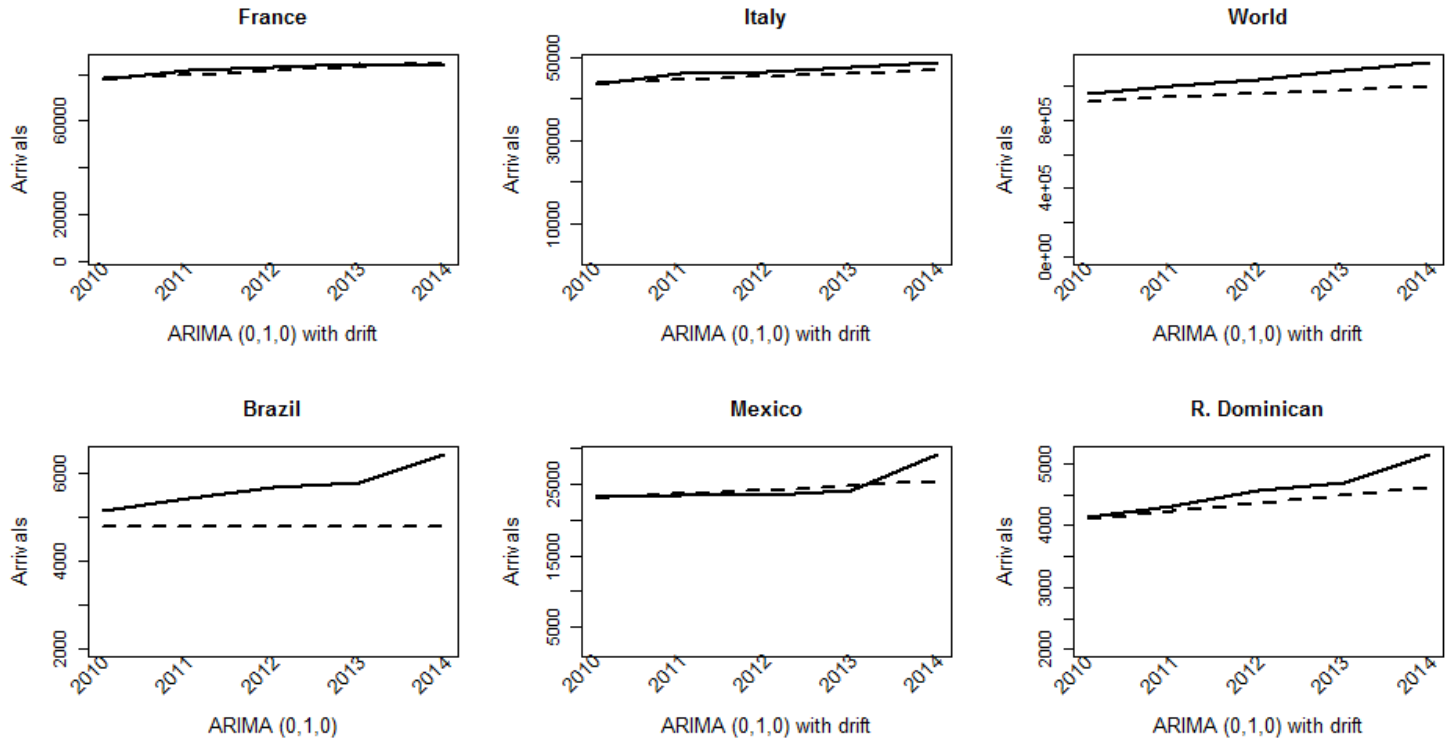

Authors own elaboration. Tourists x 1000 
Figure 6: Arab Spring impact on tourism flows in Tunisia controlled for World evolution.

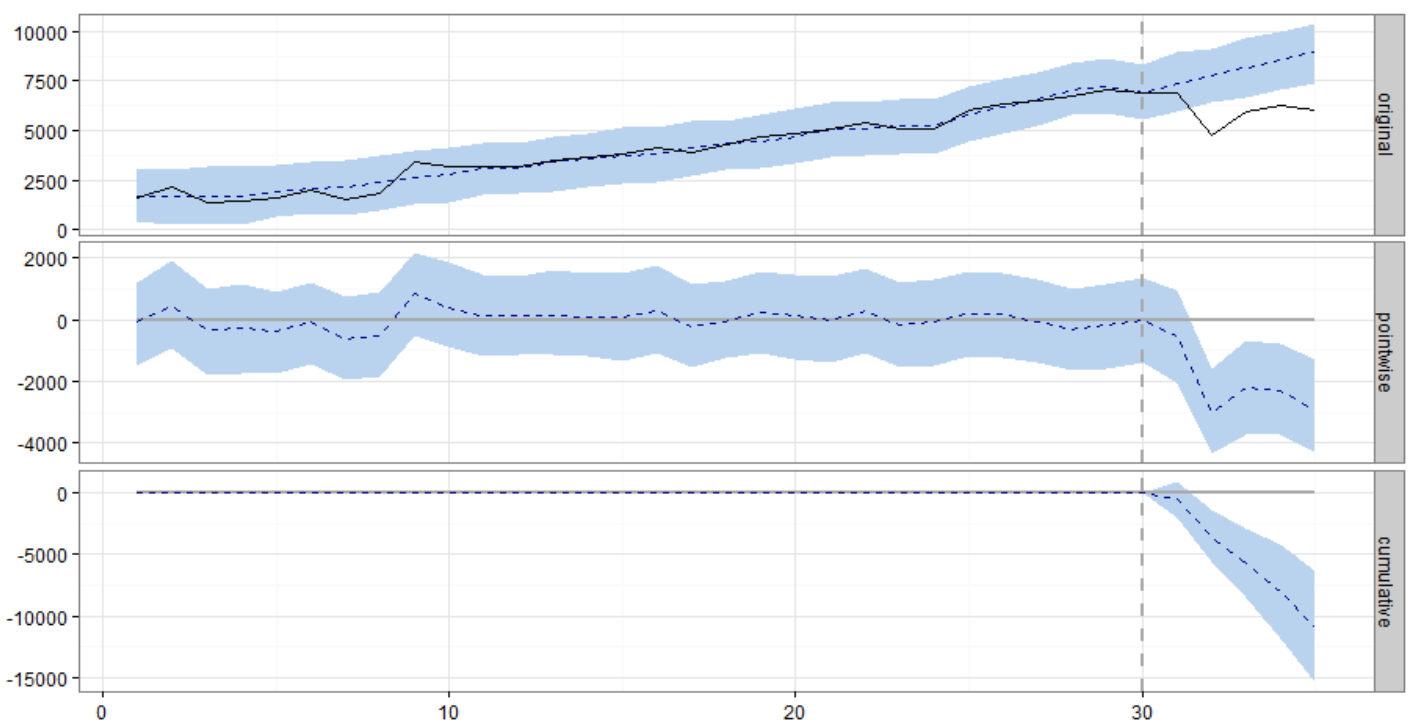

Source: CausalImpact R-package output. Note: $\mathrm{x}$ axis, observation 30 corresponds to year 2010. Upper panel shows the tourism flows (solid line) and the counterfactual prediction after Arab uprisings (dashed line). Middle panel shows the pointwise causal effect, i.e difference between observed arrivals and counterfactual predictions. Bottom panel plots the cumulative effect adding up the pointwise contributions from the middle panel. 
Figure 7: Arab Spring impact on tourism flows in Egypt controlled for World evolution.

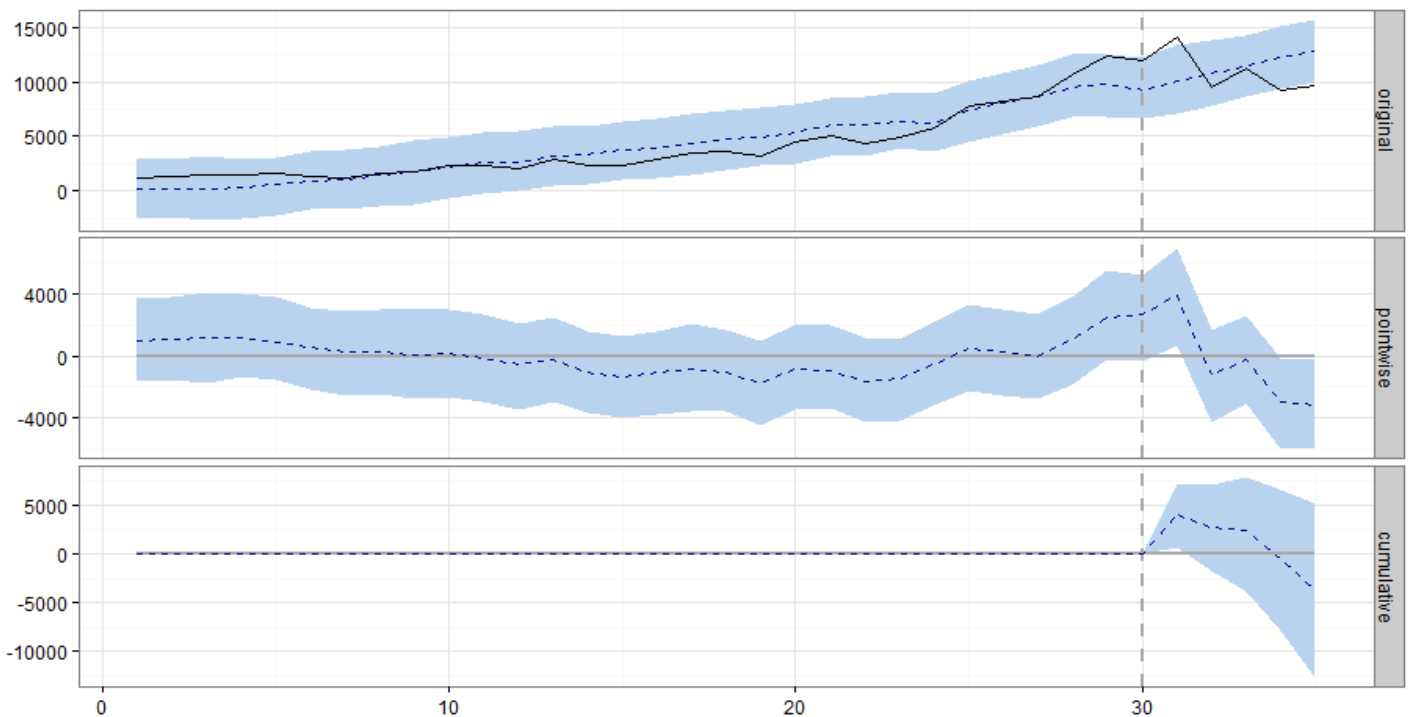

Source: CausalImpact R-package output. Note: $\mathrm{x}$ axis, observation 30 corresponds to year 2010. Upper panel shows the tourism flows (solid line) and the counterfactual prediction after Arab uprisings (dashed line). Middle panel shows the pointwise causal effect, i.e difference between observed arrivals and counterfactual predictions. Bottom panel plots the cumulative effect adding up the pointwise contributions from the middle panel. 
Table 1: Macroeconomic relevance of the tourism in MED economies, 2013-2014

\begin{tabular}{|c|c|c|c|c|}
\hline Countries & $\begin{array}{l}\% \text { of tourism and } \\
\text { travel in GDP }\end{array}$ & $\begin{array}{l}\text { \% Employment } \\
\text { total } \\
\text { contribution }\end{array}$ & $\begin{array}{l}\text { Relative } \\
\text { importance of } \\
\text { Travel \& } \\
\text { Tourism's total } \\
\text { contribution to } \\
\text { GDP } \\
\text { (out of } 184 \\
\text { countries) } \\
\text { Absolute size }\end{array}$ & $\begin{array}{l}\text { Relative } \\
\text { importance of } \\
\text { Travel \& } \\
\text { Tourism's } \\
\text { total } \\
\text { contribution to } \\
\text { GDP } \\
\text { (out of } 184 \\
\text { countries) }\end{array}$ \\
\hline & & & & Relative size \\
\hline Algeria* & 8.0 & 7.1 & 55 & 11 \\
\hline Egypt & 12.8 & 11.6 & 31 & 61 \\
\hline Israel & 7.3 & 7.8 & 46 & 119 \\
\hline Jordan & 20.3 & 17.9 & 69 & 34 \\
\hline Lebanon & 21.1 & 20.3 & 63 & 32 \\
\hline Libya & 6.7 & 4.4 & 89 & 153 \\
\hline Morocco & 17.9 & 16.0 & 49 & 39 \\
\hline Syria* & 10.6 & 7.8 & 93 & 74 \\
\hline Tunisia & 15.2 & 13.9 & 71 & 48 \\
\hline Turkey* & 12.3 & 9.1 & 14 & 63 \\
\hline
\end{tabular}

*2013. Source. World Travel and Tourism Council (WTTC). Travel and Tourism Economic Impact, several country reports 2013-2014 
Table 2: Number of hotels and rooms of Spanish International Hotel Chains.

\begin{tabular}{|c|c|c|c|c|c|c|}
\hline \multirow[b]{2}{*}{ Country } & \multicolumn{2}{|c|}{2010} & \multicolumn{2}{|c|}{2014} & \multicolumn{2}{|c|}{ Variation $10 / 14$} \\
\hline & Hotels & Rooms & Hotels & Rooms & Hotels & Rooms \\
\hline Tunisia & 32 & 9,402 & 22 & 7,249 & $-31,25$ & $-22,90$ \\
\hline Morocco & 10 & 3,665 & 12 & 3,927 & 20 & 7,15 \\
\hline Egypt & 5 & 980 & 7 & 2,005 & 40 & 104,59 \\
\hline Turkey & 8 & 2,433 & 7 & 2,126 & $-12,5$ & $-12,62$ \\
\hline North Africa & 55 & 16,480 & 48 & 15,307 & $-12,73$ & $-7,12$ \\
\hline Other countries & 846 & 21,6196 & 835 & 21,7726 & $-1,30$ & 0,71 \\
\hline $\begin{array}{l}\text { World (except } \\
\text { Spain) }\end{array}$ & 901 & 23,2676 & 883 & 23,3033 & $-2,00$ & 0,15 \\
\hline
\end{tabular}

Authors own elaboration. Source: Hosteltur (2010, 2014). 
Table 3: Predicted and real international tourist arrivals 2010-2014. ARIMA models.

\begin{tabular}{|l|l|l|l|l|}
\hline Country & $\begin{array}{l}\text { Accumulated } \\
\text { Predicted arrivals } \\
2010-2014(\mathrm{x} 1000)\end{array}$ & $\begin{array}{l}\text { International } \\
\text { tourists arrivals } \\
2010-2014(\mathrm{x} 1000)\end{array}$ & $\begin{array}{l}\text { Absolute } \\
\text { Effect }\end{array}$ & Relative Effect \\
\cline { 2 - 5 } & $(1)$ & $(2)$ & $(3)$ & $(4)$ \\
\hline Tunisia & 38062 & 29.976 & -8.086 & $-21.24 \%$ \\
\hline Egypt & 70.281 & 53.546 & -16.735 & $-23.81 \%$ \\
\hline Morocco & 46.408 & 48.333 & +1.925 & $+4.14 \%$ \\
\hline Greece & 79.808 & 86.905 & +7.097 & $+8.89 \%$ \\
\hline Turkey & 209.546 & 179.392 & -30.154 & $-14.39 \%$ \\
\hline Spain & 275.773 & 292.201 & +16.428 & $+5.95 \%$ \\
\hline
\end{tabular}

Authors own elaboration. 
Table 4: Estimated Impact of the Arab Spring on international tourist arrivals 20102014.

\begin{tabular}{|c|c|c|c|c|c|}
\hline \multirow[t]{3}{*}{ Country } & \multirow{2}{*}{$\begin{array}{l}\text { ARIMA } \\
\text { (columns } \\
3 \text { and } 4 \text { of } \\
\text { Table 3) }\end{array}$} & \multicolumn{4}{|c|}{$\begin{array}{l}\text { Analysis using CausalImpact (Brodersen et al, 2015) } \\
\text { Countries used as a control }\end{array}$} \\
\hline & & World & $\begin{array}{l}\text { World, Mexico } \\
\text { and Dominican } \\
\text { Republic }\end{array}$ & France and Italy & $\begin{array}{l}\text { France, Italy, } \\
\text { Mexico, } \\
\text { Dominican } \\
\text { Republic }\end{array}$ \\
\hline & (1) & (2) & (3) & (4) & (5) \\
\hline Tunisia & $\begin{array}{l}-8.086 \\
-21.24 \%\end{array}$ & $\begin{array}{l}-10.960 \\
-27 \% \\
(-38 \%,-16 \%)\end{array}$ & $\begin{array}{l}-9.750 \\
-25 \% \\
(-37 \%,-11 \%)\end{array}$ & $\begin{array}{l}-3.930 \\
-12 \% \\
(-2.6 \%,+2.2 \%)\end{array}$ & $\begin{array}{l}-7.932 \\
-21 \% \\
(-33 \%,-8.6 \%)\end{array}$ \\
\hline Egypt & $\begin{array}{l}-16.735 \\
-23.81 \%\end{array}$ & $\begin{array}{l}-3.738 \\
-6.5 \% \\
(-21 \%,+8.2 \%)\end{array}$ & $\begin{array}{l}-9.376 \\
-15 \% \\
(-32 \%,+3.5 \%)\end{array}$ & $\begin{array}{l}+3.064 \\
+6.1 \% \\
(-14 \%,+28 \%)\end{array}$ & $\begin{array}{l}-6.389 \\
-11 \% \\
(-25 \%,+5.5 \%)\end{array}$ \\
\hline Morocco & $\begin{array}{l}+1.925 \\
+4.14 \%\end{array}$ & $\begin{array}{l}+8.533 \\
+21 \% \\
(+7.9 \%,+35 \%)\end{array}$ & $\begin{array}{l}+8.198 \\
+20 \% \\
(+5.38 \%,+37 \%)\end{array}$ & $\begin{array}{l}+15.667 \\
+48 \% \\
(+29 \%,+65 \%)\end{array}$ & $\begin{array}{l}+11.033 \\
+30 \% \\
(+15 \%,+43 \%)\end{array}$ \\
\hline Greece & $\begin{array}{l}+7.097 \\
+8.89 \%\end{array}$ & $\begin{array}{l}-7.008 \\
-7.5 \% \\
(-17 \%,+2.9 \%)\end{array}$ & $\begin{array}{l}-3.527 \\
(-3.9 \%) \\
(-15 \%,+8 \%)\end{array}$ & $\begin{array}{l}+5.526 \\
+6.8 \% \\
(-4.1 \%,+17 \%)\end{array}$ & $\begin{array}{l}-386 \\
-0.44 \% \\
(-11 \%,+12 \%)\end{array}$ \\
\hline Turkey & $\begin{array}{l}-30.154 \\
-14.39 \%\end{array}$ & $\begin{array}{l}+38.487 \\
+27 \% \\
(+11 \%,+43 \%)\end{array}$ & $\begin{array}{l}+23.108 \\
+15 \% \\
(-5.5 \%,+33 \%)\end{array}$ & $\begin{array}{l}+59.420 \\
+50 \% \\
(+29 \%,+70 \%)\end{array}$ & $\begin{array}{l}+39.382 \\
+28 \% \\
(+8.9 \%,+48 \%)\end{array}$ \\
\hline Spain & $\begin{array}{l}+16.428 \\
+5.95 \%\end{array}$ & $\begin{array}{l}-33.132 \\
-10 \% \\
(-19 \%,-1.6 \%)\end{array}$ & $\begin{array}{l}-19.301 \\
-6.2 \% \\
(-16 \%,+2.7 \%)\end{array}$ & $\begin{array}{l}+9.849 \\
+3.5 \% \\
(-6.3 \%,+14 \%)\end{array}$ & $\begin{array}{l}-16.612 \\
-5.4 \% \\
(-14 \%,+3.1 \%)\end{array}$ \\
\hline
\end{tabular}

Authors own elaboration. First row cumulative 2010-2014 absolute effect. Second row cumulative relative effect. Third row $95 \%$ posterior confidence interval of cumulative relative effect. 